\title{
DETACHED LEAF ASSAY FOR in vitro SCREENING OF POTENTIAL BIOCONTROL AGENTS TO CONTROL GOOSEGRASS WEED (Eleusine indica)
}

\author{
MOHAMED MAIZATUL-SURIZA*; IDRIS A SEMAN *; AHMAD ZAIRUN MADIHAH* \\ and M HEFNI RUSLI*
}

\begin{abstract}
Eleusine indica (goosegrass) is a hard to control tropical grass weed that thrives in open spaces with full sunlight and is one of the many weeds found in oil palm plantations in Malaysia. The use of biocontrol agents (BCA) to manage E. indica offers specificity and environmentally safer alternatives to chemical control and help reduces a widespread incidence of herbicide resistance. In vitro detached leaf assay has been carried out to screen for potential BCA to suppress the infestation of E. indica. A total of 190 fungi were isolated from the diseased parts of $\mathrm{E}$. indica which originated from oil palm plantations and were tested for its potential as BCA. Leaves of E. indica were floated in vitro on a $0.5 \%$ w/v agar media supplemented with $100 \mu \mathrm{g} \mathrm{ml}^{-1}$ benomyl and inoculated with mycelial plugs of the isolated fungi. Four isolates namely G5S5, G5S1, G11S3 and G11L24 were observed to be pathogenic to the targeted weed in vitro, showing initial evidence as potential BCA to suppress E. indica.
\end{abstract}

Keywords: biocontrol agent (BCA) of weeds, in vitro screening, detached leaf assay, Eleusine indica, goosegrass.

Date received: 5 June 2017; Sent for revision: 6 June 2017; Received in final form: 9 August 2017; Accepted: 11 August 2017.

\section{INTRODUCTION}

Weeds pose a serious constraint to the production of any crops because vigorous growth of weed competes with the main crops. In Malaysian oil palm plantations, yield losses of $6 \%$ to $20 \%$ have been reported (Chung, 1996) due to nutrients rivalry of the oil palm with weeds (Chung, 1997). One of the noxious weeds in oil palm cultivation especially in the nursery and young planting areas is the Eleusine indica (goosegrass). This weed has been found in $82.2 \%$ of the immature oil palm plantations with $30 \%$ of them having medium to high coverage (>25\%) (Maizatul-Suriza and Idris, 2012) and has

Malaysian Palm Oil Board,

6 Persiaran Institusi, Bandar Baru Bangi,

43000 Kajang, Selangor, Malaysia.

E-mail: suriza@mpob.gov.my been listed as a serious and dominant weed in 42 countries (Holm et al., 1977).

Herbicides have typically been used to eliminate E. indica. However, excessive use of herbicides has led to a widespread incidence of herbicide resistance and cross herbicide resistance in various species of weeds (Baker and Terry, 1991). There are more than 350 herbicide-resistant weed biotypes, comprising of 200 weed species documented in the database of the International Survey of Herbicide Resistant Weeds (Heap, 2014). Eleusine indica has been reported to be resistant to several herbicides such as triflurin (Vaughn et al., 1990) and other herbicides from dinitroaniline group (Mudge et al., 1984; Zeng and Baird, 1997), imazapyr (Valverde et al., 1993), fluazifop-butyl, aryloxyphenoxy-propionate, cyclohexanedione (Leach et al., 1995) and glyphosate (Lee and Ngim, 2000). Chuah and Sahid (2010) reported herbicide-resistant biotypes of E. indica in 
the Malaysian oil palm and rubber plantations. The rise of herbicide-resistant weed biotypes has partly driven the upsurge of interest in biological control of weeds as potential environmentally benign and effective methods of weeds control. Biological control involves the use of biotic agents such as insect pests and microbes to suppress weeds. In Malaysia, several cases of classical biological control of weeds involving the introduction of exotic insect pests have been initiated but has failed to establish such as Liothrips mikaniae imported from Trinidad to suppress Mikania micrantha (Liau et al., 1994) and an arctiid moth to control Chromolaena odorata in the oil palm plantations (Turner and Gillbanks, 2003).

The use of microbes (fungi or bacteria) to control weeds is a newer concept compared to insects and has been successfully used in weeds management; usually employed using an inundative approach which involves microbial application in massive doses to create an epidemic within the target weed population (Watson, 1993). Biocontrol using microbes offers specificity in controlling target weeds, is environmentally safe and avoids herbicide resistance in weed biotypes. Biological control is biodegradable, thus poses a negligible pollution problem and has low risks to non-target injuries (phytotoxicity) from spray drift, soil leaching, or toxicity to non-target organisms such as beneficial insects and aquatic organisms. In Hawaii, several
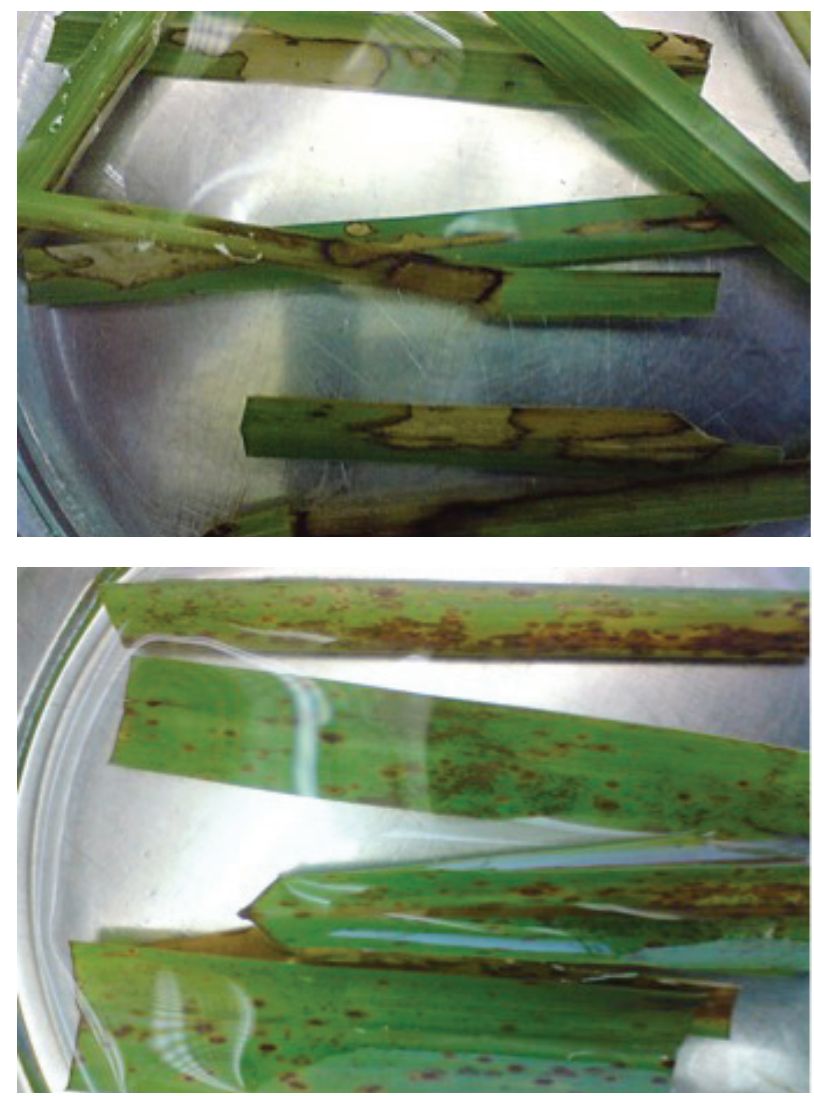

Figure 1. Symptoms on the diseased E. indica leaf sampled from the field in Selangor, Malaysia. successes of microbes to control weeds such as the white smut Entyloma compositarum on Ageratina riparia (Hamakua 'Pa-makani') have been reported (Trujillo, 2005). Currently, microbes have not been employed to control weeds in oil palm plantations in Malaysia. However, several potential fungi have been screened worldwide to control several weeds species that are also found in Malaysian oil palm plantations such as Mikania micrantha (Barreto and Evans, 1995) and Chromolaena odorata (Elango et al., 1993). In this article, we described the isolation and screening of potential fungi as biocontrol agents (BCA) to control goose grass weed, E. indica using in vitro detached leaf assay as an initial step to discover alternatives to chemical control of weeds in oil palm plantations as a strategy towards sustainability in agricultural practices.

\section{MATERIALS AND METHODS}

\section{Isolation of Microbes from Diseased E. indica}

Field isolation of microbes from diseased E. indica was carried out at an oil palm plantation in Bangi, Selangor, Malaysia. Plant parts with diseased symptoms such as brownish/yellowish spots, lesions with reddish/brownish margins and yellow / brown lesions were collected in the morning (Figure 1), placed in brown paper, and immediately transported to the laboratory.

The samples [leaf, stem and seed/flower head (inflorescence)] were surface sterilised by rinsing with tap water and submerged in $1 \% \mathrm{v} / \mathrm{v}$ sodium hypochlorite for approximately 2-3 s and washed twice with sterile distilled water. Each part was cut into small pieces (about $4 \mathrm{~mm}^{2}$ ) using sterile scalpel blades and plated on $1 \% \mathrm{w} / \mathrm{v}$ water agar and potato dextrose agar (PDA) supplemented with antibiotics (50 $\mathrm{gg} \mathrm{ml} \mathrm{gl}^{-1}$ penicillin and $100 \mu \mathrm{g} \mathrm{ml} \mathrm{m}^{-1}$ ampicillin). Fungal mycelia growing from the plant tissue was excised and transferred to fresh PDA after three to four days of incubation by hyphal tipping.

\section{Propagation E. indica Plant Material}

Seeds were collected from plants with mature seeds, air dried and kept at room temperature in dry conditions. Prior to germination, the seeds were soaked in sterile distilled water overnight and were sown in a soil mix containing soil compost and perlite (10:1). Germination trays were kept in a growth chamber at $28^{\circ} \mathrm{C}-30^{\circ} \mathrm{C}$ in $12 \mathrm{hr}$ light and $12 \mathrm{hr}$ dark regime. The media was kept moist to promote germination. Young seedlings $(7-8 \mathrm{~cm}$ in size) were then transferred to pots and maintained in the growth chamber for two to three weeks before being transferred to the nursery. Seedlings were watered and fertilised accordingly. 


\section{Detached Leaf Bioassay}

Preceding artificial inoculation with the fungal isolates, an assay to determine suitable media for the detached leaf bioassay was carried out by plating the leaves on different agar media of $0.5 \%$ $\mathrm{w} / \mathrm{v}, 1 \% \mathrm{w} / \mathrm{v}$ and $2 \% \mathrm{w} / \mathrm{v}$ with added antibiotic

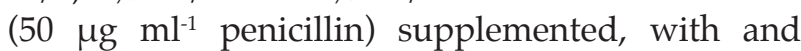
without benomyl or carbendazim at $10 \mu \mathrm{g} \mathrm{ml}^{-1}, 100$ $\mu \mathrm{g} \mathrm{ml}^{-1}$ and $200 \mu \mathrm{g} \mathrm{ml}^{-1}$. The prepared media were poured into $9 \mathrm{~mm}$ Petri dishes. A suitable media must be able to retain turgidity of the leaf pieces until symptoms develop, usually between 7-14 days after inoculation. Young leaves of E. indica were excised and collected from the potted seedlings in the evening, washed with tap water, and cut into 7-8 $\mathrm{cm}$ lengths. The leaf fragments were then surface sterilised using $0.5 \% \mathrm{v} / \mathrm{v}$ sodium hypochlorite followed by $30 \% \mathrm{v} / \mathrm{v}$ ethanol and sterile distilled water. Approximately $1 \mathrm{~cm}$ of both ends from each fragments was cut off. Three leaf pieces were plated per Petri dish in triplicates. Samples were observed and noted based on the number of green and turgid leaves.

Leaves of E. indica were floated on $0.5 \% \mathrm{w} / \mathrm{v}$ agar supplemented with $100 \mu \mathrm{g} \mathrm{ml}^{-1}$ benomyl prior to in vitro inoculation. A sterile and sharp scalpel blade was used to wound the leaves at the middle of each fragment. A mycelial plug (approximately $5 \mathrm{~mm}$ in diameter) from active growing margins of 7-day old PDA agar cultures of fungi isolated from diseased E. indica was placed on the wounded site. All Petri dishes were sealed using Parafilm ${ }^{\circledR}$ to maintain moisture and incubated in a growth chamber set at $25^{\circ} \mathrm{C}$ at $10 \mathrm{hr}$ light approximately (18 $\left.\mu \mathrm{E} \mathrm{m}^{-2} \mathrm{~s}^{-1}\right)$, and $14 \mathrm{hr}$ dark. The presence of lesion(s) or other disease symptoms were monitored every day for seven days. The assay was done in triplicates for each isolate.

\section{Molecular Identification of Microbes}

DNA extraction. Mycelial tissues of the 7-10 days old fungi cultures were scraped from the agar media and homogenised using $2 \mathrm{~mm}$ and $4 \mathrm{~mm}$ glass beads with a miller. DNA extraction was carried out using DNeasy ${ }^{\circledR}$ Plant Mini Kit (Qiagen, USA) following the manufacturer's protocol.

Amplification of internal transcribed spacer (ITS) marker. Polymerase chain reaction (PCR) amplification was performed in $30 \mu \mathrm{l}$ volumes consisting of $15 \mu \mathrm{l}$ of master mix (2x MangoTaq ${ }^{\mathrm{TM}}$ DNA Polymerase), $12 \mu$ l sterile distilled water, 1 $\mu \mathrm{l}$ of template fungal DNA and $1 \mu \mathrm{l}\left(10 \mathrm{pmol}^{-1}\right)$ each of forward (ITS1 5'-TCC GTA GGT GAA CCT GCG G-'3) and reverse primers (ITS4 5'-TCC TCC GCT TAT TGA TAT GC-'3) (White et al., 1990). PCR conditions were denaturation at $95^{\circ} \mathrm{C}$ for $2 \mathrm{~min}, 35$ amplification cycles at $95^{\circ} \mathrm{C}, 2 \mathrm{~min} ; 55^{\circ} \mathrm{C}, 1 \mathrm{~min}$; $72^{\circ} \mathrm{C}, 1 \mathrm{~min}$ for $30 \mathrm{~s}$, and a final elongation step at $72{ }^{\circ} \mathrm{C}$ for $10 \mathrm{~min}$. PCR products were observed via gel electrophoresis using $1.2 \% \mathrm{w} / \mathrm{v}$ agarose gels stained with ethidium bromide in Tris-borateEDTA run in (TBE) buffer at 100 volts for 25-40 min. The amplified products were purified using the QIAquick ${ }^{\circledR}$ PCR Purification Kit (Qiagen, USA) following manufacturer's instructions and were then sent for DNA sequencing ( $1^{\text {st }}$ Base Sdn Bhd, Malaysia) with the same primer pairs used in the PCR amplifications.

Sequences analyses of ITS. The sequences were checked and cleaned using the GAP4 software package (Staden-package, USA) by removing vector sequences, correcting base errors, and generating contig sequences of forward and reverse sequences of each individual isolate. We then subjected the ITS nucleotides sequence to nucleotide-nucleotide searches via Genbank sequence database using the Basic Local Alignment Search Tool - BLASTn algorithm from NCBI's website (http: / / www.ncbi. nlm.nih.gov / BLAST/ ). Identification of each isolate was based on maximum scoring of identity value and query coverage.

\section{RESULTS}

\section{Isolation of Microbes from Diseased E. indica}

Fungi from the diseased leaves were isolated from water agar plates as it was easier to obtain individual hyphae compared to the PDA isolates. A total of 190 isolates were collected and grouped (11 groups) based on morphological characteristics of the colony on the PDA agar plates (Table 1) (Figure 2). Group G1 is characterised by thick reddish with yellowish-patch cottony colonies with some aerial

TABLE 1. NUMBER OF FUNGI ISOLATED FROM LEAF, STEM AND SEED HEADS OF Eleusine indica

\begin{tabular}{lcccc}
\hline \multirow{2}{*}{ Group } & \multicolumn{2}{c}{ Diseased part of Eleusine indica } & \multirow{2}{*}{ Total } \\
\cline { 2 - 3 } & Leaf & Stem & Head & \\
\hline G1 & 6 & 21 & 9 & 36 \\
G2 & 27 & 12 & 8 & 47 \\
G3 & 25 & 15 & 12 & 52 \\
G4 & 30 & 6 & 0 & 36 \\
G5 & 0 & 2 & 0 & 2 \\
G6 & 3 & 0 & 0 & 3 \\
G7 & 3 & 0 & 0 & 3 \\
G8 & 3 & 0 & 0 & 3 \\
G9 & 3 & 0 & 0 & 3 \\
G10 & 3 & 0 & 0 & 3 \\
G11 & 1 & 1 & 0 & 2 \\
\hline Total & 104 & 57 & 29 & 190 \\
\hline
\end{tabular}




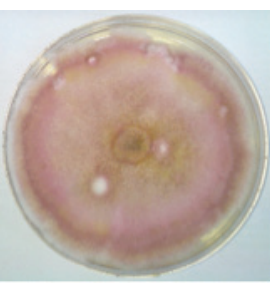

(a)

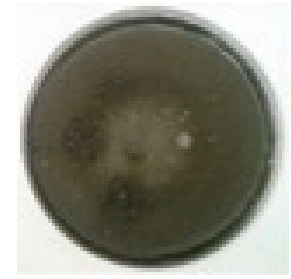

(f)

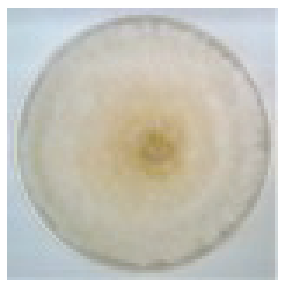

(b)

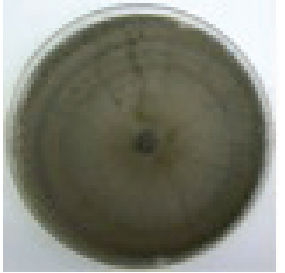

(g)

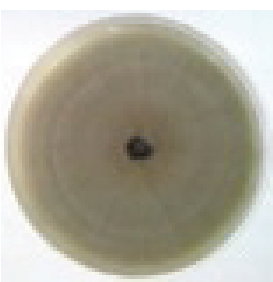

(c)

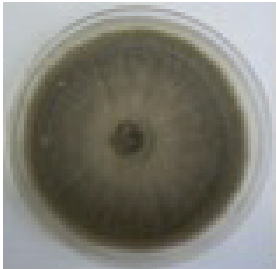

(h)

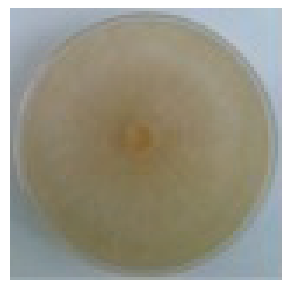

(d)

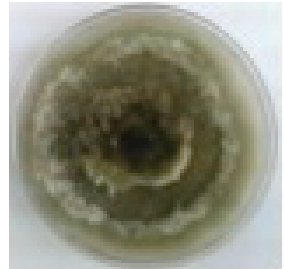

(i)

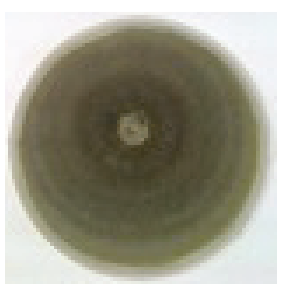

(e)

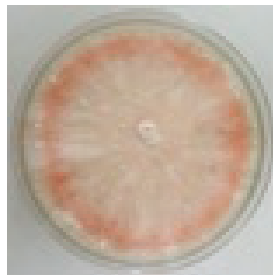

(j)

Figure 2. Morphology of the colonies of fungi isolated from diseased E. indica (from top left: a) G1S7, b) G2F3, c) G4L22, d) G6L2, e) G7L24, f) G8L30, g) G9L3, h) G10L6, i) G11L24, and j) G5S5). Groups G1 and G2, are similar in appearance except for the reddish colour observed in G1. Groups G4, G7, G8, G9, G10 and G11 are greenish colonies. Group G6 is a yellowish colony and group G5 has orange/red marginal ring colonies.

mycelia. Colonies of G2 have similar appearances with G1 but without the reddish colour. Mycelial colonies of G2 and G6 are pale yellowish white but colonies of G6 did not grow as thick as the colonies of G2. Groups G3 and G11 have thick cottony mycelia, greenish in colour with white thick cottony ring patches. However G11 colonies were observed with thinner mycelial mats. Colonies of G5 have velvet ivory white mycelia with red marginal rings. Groups G4, G7, G8, G9, and G10 have similar dusty, greenish thin mycelia and are suspected to be of the same species but were separated due to different colour intensities and were treated as individual groups.

\section{Screening of Potential Biocontrol Microbes to Control E. indica}

Senescence occurred as early as the next day after incubation on solid $1 \% \mathrm{w} / \mathrm{v}$ and $2 \% \mathrm{w} / \mathrm{v}$ agar but slower on semi-solid $0.5 \% \mathrm{w} / \mathrm{v}$ agar (Table 2).
The addition of benomyl and carbendazim were observed to prolong the leaves' freshness for up to several days. Eleusine indica leaves floated on semi-solid $0.5 \% \mathrm{w} / \mathrm{v}$ agar supplemented with 100 $\mu \mathrm{g} \mathrm{ml} \mathrm{m}^{-1}$ benomyl were significantly preserved for up to seven days after incubation compared to other media tested and were subsequently used in screening assays. For the screening assay, two isolates of G5 and two isolates of G11 were observed to cause lesions to E. indica leaves on Day 2 after inoculation (Figure 3). There were no infections observed for other isolates. PCR amplification of the four potential isolates produced amplicons of approximately $600-700 \mathrm{bp}$.

\section{DISCUSSION}

The detached leaf assay is a simple in vitro method to evaluate the pathogenicity and virulence of a microbe causing foliar diseases of plant (Pettitt et al.,

TABLE 2. DETERMINATION OF A SUITABLE MEDIA FOR THE DETACHED LEAF ASSAY OF Eleusine indica

\begin{tabular}{|c|c|c|c|c|c|c|c|}
\hline \multirow{2}{*}{ Media } & \multicolumn{7}{|c|}{ Percentage of fresh leaves* (at $n$ day after incubation) } \\
\hline & $\mathrm{n}=1$ & 2 & 3 & 5 & 7 & 11 & 14 \\
\hline Agar $0.5 \%$ & $100 \mathrm{a}$ & $100 \mathrm{a}$ & $100 \mathrm{~b}$ & $96.3 a$ & $66.7 \mathrm{~b}$ & $40.7 \mathrm{~cd}$ & $0 b$ \\
\hline Agar $1 \%$ & $96.3 \mathrm{a}$ & $51.9 b$ & $33.3 b$ & $11.1 \mathrm{~b}$ & $0 \mathrm{e}$ & Of & $0 b$ \\
\hline Agar $2 \%$ & $74.1 \mathrm{~b}$ & $40.7 b$ & $14.8 \mathrm{~b}$ & 0c & $0 \mathrm{e}$ & Of & $\mathrm{Ob}$ \\
\hline Agar $0.5 \%+10 \mu \mathrm{g} \mathrm{ml}^{-1}$ benomyl & $100 \mathrm{a}$ & $100 \mathrm{a}$ & $96.3 a$ & $96.3 a$ & $77.8 b$ & $63.0 \mathrm{ab}$ & $40.7 \mathrm{a}$ \\
\hline Agar $0.5 \%+100 \mu \mathrm{g} \mathrm{ml}^{-1}$ benomyl & $100 \mathrm{a}$ & $100 \mathrm{a}$ & $100 \mathrm{a}$ & $100 \mathrm{a}$ & $100 \mathrm{a}$ & $70.4 \mathrm{a}$ & $40.7 \mathrm{a}$ \\
\hline Agar $0.5 \%+200 \mu \mathrm{g} \mathrm{ml}^{-1}$ benomyl & $100 \mathrm{a}$ & $100 \mathrm{a}$ & $100 \mathrm{a}$ & $100 \mathrm{a}$ & $70.4 b$ & $48.1 \mathrm{cb}$ & $29.6 a$ \\
\hline Agar $0.5 \%+10 \mu \mathrm{g} \mathrm{ml}^{-1}$ carbendazim & $100 \mathrm{a}$ & $100 \mathrm{a}$ & $100 \mathrm{a}$ & $100 \mathrm{a}$ & 18.5de & 3.7ef & $0 b$ \\
\hline Agar $0.5 \%+100 \mu \mathrm{g} \mathrm{ml}^{-1}$ carbendazim & $100 \mathrm{a}$ & $100 \mathrm{a}$ & $100 \mathrm{a}$ & $100 \mathrm{a}$ & $44.4 \mathrm{c}$ & 22.2de & $11.1 \mathrm{~b}$ \\
\hline Agar $0.5 \%+200 \mathrm{\mu g} \mathrm{ml}^{-1}$ carbendazim & $100 \mathrm{a}$ & $100 \mathrm{a}$ & $100 \mathrm{a}$ & $100 \mathrm{a}$ & $37 \mathrm{~cd}$ & 22.2de & $7.4 \mathrm{~b}$ \\
\hline
\end{tabular}

Note: *Values are mean of percentage based of 27 leaf fragments (replicates) and values with the same letter in the same column are not significant based on Fisher's Least Significant Difference Test at $\mathrm{P}=0.05$. 

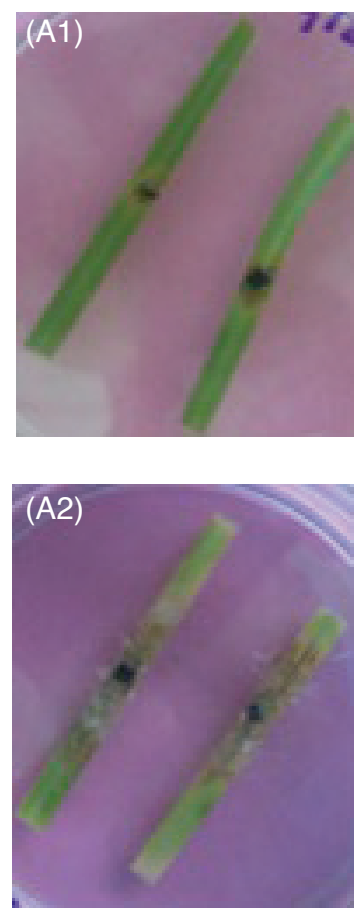
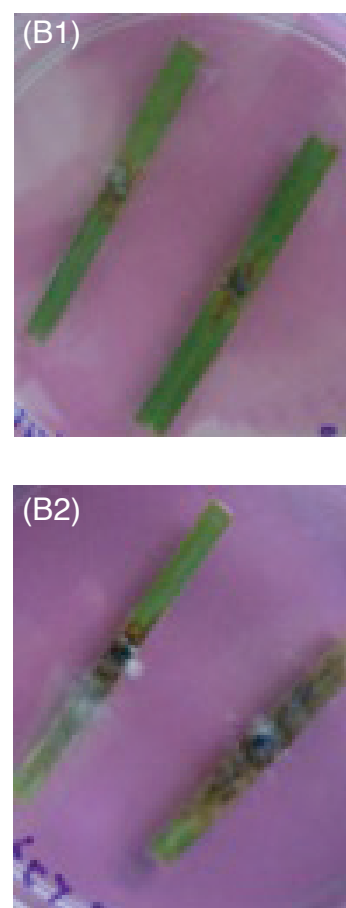
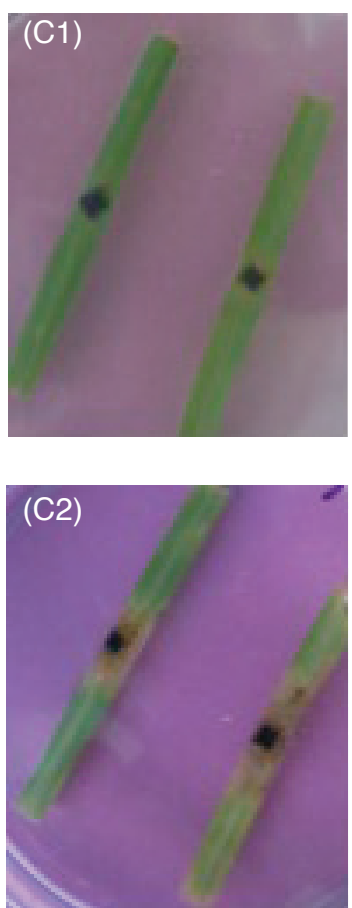
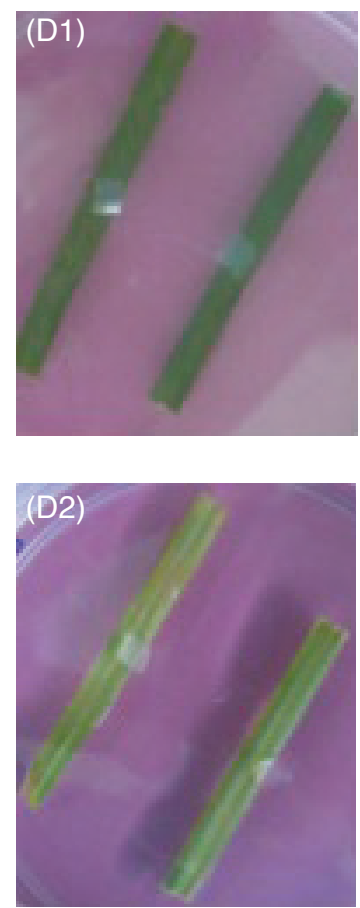

Figure 3. Infection on the leaf of E. indica caused by fungi isolate; A) G11S3, B) G11L24 and C) G5S5 at two days after inoculation (A1, B1 and C1) and five days after inoculation (A2, B2 and C2). Control assay was carried out using a blank clean PDA plug and was observed to cause no infection at two and five days after inoculation (D1 and D2, respectively).

2011; Cowley et al., 2012) and can also be used to screen for potential BCA against weeds (Chiang et al., 1989; Saxena and Pandey, 2002). A detached leaf assay is more rapid, economic, and do not require large spaces (Sinclair and Dhingra, 1995). Hence, it is more suitable for screening a large number of microbes during the initial stages. The challenge of employing the detached leaf assay is to ensure that the leaves are fresh, living, and turgid until symptoms develop as we want to take advantage of parasitic microbes that are able to infect and damage the living tissue while avoiding saprophytic microbes feeding off of the necrotic tissue.

Detached leaf assays on several grass species such as crus-galli (Echinochloa sp.) (Zhang and Watson, 2000) and Johnson grass (Sorghum halpense) (Chiang et al., 1989) has been successfully conducted on PDA agar and wet cotton. Jia et al. (2003) placed segments of detached rice (Oryza sativa) leaves onto a Petri dish lined with moist filter paper and conidial suspension of the fungal pathogen Magnaporthe grisae was added with $0.02 \% \mathrm{v} / \mathrm{v}$ Tween 20 and $0.25 \% \mathrm{w} / \mathrm{v}$ gelatin. This method was then modified by Takahashi et al. (2009) by introducing the filter paper inoculation method for inoculating Italian ryegrass with Pyricularia oryzae.

Nevertheless, the same method was not suitable for E. indica due to its delicate, small, and thin leaves which dry off easily. We have found that semi-solid agar at $0.5 \% \mathrm{w} / \mathrm{v}$ supplemented with benomyl or carbendazim $\left(100 \mu \mathrm{g} \mathrm{ml}^{-1}\right)$ works best to prolong the freshness of E. indica leaves compared to solid agar. Carbendazim at $100 \mu \mathrm{g} \mathrm{ml}^{-1}$ was also used in detached leaf assays using wheat seedling leaves (Arraiano et al., 2001).

Four isolates G5S5, G5S1, G11S3, and G11L24 were shown to cause lesions on E. indica at two days after inoculation. Small, yellowish lesions were observed in some leaves one day after inoculation with G11S3 and G11L24. Isolates G11S3, G5S5, and G5S1 were isolated from diseased stems, while G11L24 was isolated from diseased leaves of E. indica. Isolates G11S3 and G5S5 were isolated from the stems of E. indica but was able to cause lesions on the leaves suggesting that they have a higher potential of damaging the whole plant. Although many isolates from groups G1, G2, G3, and G4 were obtained, none were able to cause foliar damage to E. indica; probable indication of saprophytic fungi colonies. The large number of saprophytic fungi isolated was due to the short period (2-3 s) of leaf surface sterilisation using $1 \% \mathrm{v} / \mathrm{v}$ sodium hypochlorite during isolation. However, due to the thin and delicate nature of $E$. indica leaves, submersion for an extended period in the solution will scorch the leaf.

Identification of these potential fungi was carried out using molecular characterisation based on ITS of ribosomal RNA (rRNA) gene cluster of genomic DNA. The sequences encoding for rRNA, particularly the ITS region has been extensively used in the identification of fungi and oomycetes up to the species level, although some other regions have also been explored and used in identification 
and barcoding of fungi such as cytochrome oxidase I (COXI) (Seifert, 2009; Diaz et al., 2012) due to many reasons. The ITS region is omnipresent and can be found in all eukaryotes, providing wider coverage. This region consists of two small regions, ITS1 and ITS2, which are situated within ribosomal gene clusters between the conserved flanking regions of the small subunit (SSU 18S) and large subunits (LSU 28S) of ribosomal RNA on either sides of the 5.8S rRNA gene. The rDNA region is highly stable and exhibits a mosaic of conserved and diverse regions within a genome (Hibbett, 1992). The rDNA has a high copy number which allows highly sensitive PCR amplifications (Capote et al., 2012). Furthermore, a large number of ITS sequences are openly available in sequence databases.

Sequence alignments (BLAST) of nucleotides from isolate G11S3 (GenBank MF095675) with nucleotide sequences in the GenBank database showed a similarity (99\% identity, 99\% query cover, 593 maximum score) to Bipolaris sorokiniana (GenBank KF494823) and G11L24 (GenBank MF095676) was similar (100\% identity, 99\% query cover, 1013 maximum score) to Bipolaris sp. (GenBank KX452450). Nucleotides of isolate G5S5 (GenBank MF095677) found to be similar (99\% identity) to Epicoccum sorghinum (GenBank KY454467) and Phoma sp. (GenBank KM259932); both with the same maximum score of 935 and query cover of 99\%. Nucleotides of isolate G5S1 (GenBank MF095678) was also found to be similar (100\% identity) to Epicoccum sorghinum (GenBank KY454467) and Phoma sp. (GenBank KY556682) with maximum score of 935 and query cover of $100 \%$. For both isolates G5S5 and G5S1, further identification based on morphological characterisations of fungal colonies on PDA and microscopic structures show similarity to Phoma herbarum. Further evaluations on the efficacies of the potential fungal isolates will be carried out which include a host range assay to study its cross-infectivity to other plant hosts especially species of the grass family (Poaceae) with economic importance such as rice (Oryza spp.), wheat (Triticum spp.), and sorghum especially the G11 group which has been identified as a species from the genus Bipolaris which is known to cause diseases to wheat and rice. Bipolaris oryzae is the causal agent of brown spot of rice (Kumar et al., 2011; Nazari et al., 2015) while, Bipolaris sorokiniana is the causal agent of common root rot, leaf spot disease, seedling blight, head blight, and black point of wheat and barley; the disease is also reported on other grasses (Kumar et al., 2002).

\section{CONCLUSION}

We have successfully screened a total of 190 fungi isolated from Eleusine indica (goosegrass) and are able to identity four potential candidates of BCA against the weed using in vitro detached leaf assay. The detached leaf assay demonstrated to be a useful tool for the initial screening method of potential BCA to control E. indica. This in vitro method allows a larger number of microbes to be tested compared to the in planta assay method as the screening of potential microbes using the whole plant usually requires large designated spaces such as a growth room or a glasshouse.

\section{ACKNOWLEDGEMENT}

The authors are grateful to the Director-General of MPOB for permission to publish this article. The authors would also like to thank all MPOB staff for their assistance in conducting this study.

\section{REFERENCES}

ARRAIANO, L S; BRADING, P A and BROWN, J K M (2001). A detached seedling leaf technique to study resistance to Mycosphaerella graminicola (anamorph Septoria tritici) in wheat. Plant Pathology, 50(3): 339-346.

BAKER, F W G and TERRY, P J (1991). Tropical Grassy Weeds. CAB International, London. 203 pp.

BARRETO, R W and EVANS, H C (1995). The mycobiota of the weed Mikania micrantha in southern Brazil with particular reference to fungal pathogens for biological control. Mycological Research, 99(3): 343-352.

CAPOTE, N; PASTRANA, A M; AGUADO, A and TORRES , T (2012). Molecular tools for detection of plant pathogenic fungi and fungicide resistance. Plant Pathology (Cumagun, C J R ed.). InTech. www. intechopen.com, p. 151-202.

CHIANG, M Y; VAN DYKE, C G and LEONARD, K J (1989). Evaluation of endemic foliar fungi for potential biological control of johnsongrass (Sorghum halepense): screening and host range tests. Plant Disease, 73(6): 459-464.

CHUAH, T S and SAHID, I (2010). The status of weed resistance in plantation crops of Malaysia. The Planter, 86(1014): 615-620.

CHUNG, G F (1996). Weed management in oil palm. Oil Palm Plantation Management: Selected Reading (Hishamudin, M J; Shamsuri, M and Soleha, A B eds). PORIM, Bangi. p. 165-179. 
CHUNG, G F (1997). Efficient weed management. The Planter, 73(861): 645-670.

COWLEY, R B; LUCKETT, D J; HARPER, J D I and ASH, G J (2012). Development of a reliable and rapid detached leaf assay to detect resistance to the fungal disease phomopsis leaf blight, caused by Diaporthe toxica, in Lupinus albus. Canadian J. Plant Pathology, 34(3): 401-409.

DIAZ, P; HENNELL, J and SUCHER, N (2012). Genomic DNA extraction and barcoding of endophytic fungi. Plant DNA Fingerprinting and Barcoding - Methods in Molecular Biology (Sucher, N J; Hennell, J R and Carles, M C eds.). Vol. (862). Humana Press. https://link.springer.com, p. 171179.

ELANGO, D E; HOLDEN, A N G and PRIOR, C (1993). The potential of plant pathogens collected in Trinidad for biological control of Chromolaena odorata (L.). International J. Pest Management, 39(4): 393-396.

HEAP, I (2014). Herbicide resistant weeds. Integrated Pest Management: Pesticide Problems. Vol. (3). Springer, Netherlands. p. 281-301.

HIBBETT, D S (1992). Ribosomal RNA and fungal systematics. Transactions of the Mycological Society of Japan, 33: 533-556.

HOLM, L G; PLUCKNETT, D L; PANCHO, J V and HERBERGER, J P (1977). The World's Worst Weeds. University Press of Hawaii, Hawaii, USA. 621 pp.

JIA, Y;VALENT, B and LEE, FN (2003). Determination of host responses to Magnaporthe grisea on detached rice leaves using a spot inoculation method. Plant Disease, 87(2): 129-133.

KUMAR, J; SCHÄFER, P; HÜCKELHOVEN, R; LANGEN, G; BALTRUSCHAT, H; STEIN, E; NAGARAJAN, S and KOGEL, K H (2002). Bipolaris sorokiniana, a cereal pathogen of global concern: cytological and molecular approaches towards better control. Molecular Plant Pathology, 3(4): 185195.

KUMAR, P; ANSHU, V and KUMAR, S (2011). Morpho-pathological and molecular characterization of Bipolaris oryzae in rice (Oryzae sativa). J. Phytopathology, 159(1): 51-56.

LEACH, G E; DEVINE, M D; KIRKWOOD, R C and MARSHALL, G (1995). Target enzyme-based resistance to acetyl-coenzyme A carboxylase inhibitors in Eleusine indica. Pesticide Biochemistry and Physiology, 51(2): 129-136.
LEE, L J and NGIM, J (2000). A first report of glyphosate resistant goosegrass [Eleusine indica (L) Gaertn] in Malaysia. Pest Management Science, 56(4): 336-339.

LIAU, S S; TAN, C L; OOI, P A C; CHUNG, G F; LEE, S A and TAY, B L (1994). Field releases of Liothrips mikanieae (Priesner) for control of Mikania micrantha HBK - experiences in Malaysia. Proc. of the Fourth International Conference on Plant Protection in the Tropics (Rajan, A and Ibrahim, Y eds.). p. 116-119.

MAIZATUL-SURIZA, M and IDRIS, A S (2012). Occurence of common weeds in mature plantings of oil palm plantations in Malaysia. The Planter, 88(1037): 537-547.

MUDGE, L C; GOSSETT, B J and MURPHY, T R (1984). Resistance of goosegrass (Eleusine indica) to dinitroaniline herbicides. Weed Science, 32(5): 591594.

NAZARI, S; JAVAN-NIKKHAH, M; FOTOUHIFAR, K-B; KHOSRAVI, V and ALIZADEH, A (2015). Bipolaris species associated with rice plant: pathogenicity and genetic diversity of Bipolaris oryzae using rep-PCR in Mazandaran province of Iran. J. Crop Protection, 4(4): 497-508.

PETTITT, T R; WAINWRIGHT, M F; WAKEHAM, A J and WHITE, J G (2011). A simple detached leaf assay provides rapid and inexpensive determination of pathogenicity of Pythium isolates to 'all year round' (AYR) chrysanthemum roots. Plant Pathology, 60(5): 946-956

SAXENA, S and PANDEY, A K (2002). Evaluation of an indigenous isolate of Alternaria alternata (LC\# 508) for use as a mycoherbicide for Lantana camara L. Crop Protection, 21(1): 71-73.

SEIFERT, K A (2009). Progress towards DNA barcoding of fungi. Molecular Ecology Resources, 9: 83-89.

SINCLAIR, J B and DHINGRA, O D (1995). Basic Plant Pathology Methods. CRC Press, Florida, USA. $420 \mathrm{pp}$

TAKAHASHI, W; MIURA, Y and SASAKI, T (2009). A novel inoculation method for evaluation of grey leaf spot resistance in Italian ryegrass. J. Plant Pathology, 91(1): 171-176.

TRUJILLO, E E (2005). History and success of plant pathogens for biological control of introduced weeds in Hawaii. Biological Control, 33(1): 113-122.

TURNER, P D and GILLBANKS, R A (2003). Oil Palm Cultivation and Management. $2^{\text {nd }}$ edition. The 
Incorporated Society of Planters, Kuala Lumpur. p. 672.

VALVERDE, B E; CHAVES, L; GONZÁLEZ, J and GARITA, I (1993). Field-evolved imazapyr resistance in Ixophorus unisetus and Eleusine indica in Costa Rica. Proc. of the Internation Conference: Brighton Crop Protection Conference - Weeds. Brighton, United Kingdom, Vol. 3. p. 1189-1194.

VAUGHN, K C; VAUGHAN, M A and GOSSETT, B J (1990). A biotype of goosegrass (Eleusine indica) with an intermediate level of dinitroaniline herbicide resistance. Weed Technology, 4(1): 157-162.

WATSON, A K (1993). Current status of bioherbicide development and prospects for rice in Asia. ASPAC Extension Bulletin (365). ASPAC Food \& Fertilizer Technology Centre, Taipei. p. 7.
WHITE, T J; BRUNS, T; LEE, S and TAYLOR, J (1990). Amplification and direct sequencing of fungal ribosomal RNA genes for phylogenetics. PCR Protocols: A Guide to Methods and Applications. Academic Press, New York. p. 315-322.

ZENG, L and BAIRD, W V (1997). Genetic basis of dinitroaniline herbicide resistance in a highly resistant biotype of goosegrass (Eleusine indica). J. Heredity, 88(5): 427-432.

ZHANG, W and WATSON, A K (2000). Isolation and partial characterization of phytotoxins produced by Exserohilum monoceras, a potential bioherbicide for control of Echinochloa species. Proc. of the $X$ International Symposium on Biological Control of Weeds (Spencer, N R ed.). Montana, USA. p. 125-130. 